(O) $\begin{aligned} & \text { Transformasi : Jurnal Pendidikan Matematika dan Matematika } \\ & \text { Volume 5, No. 1, Bulan Juni Tahun 2021, pp.455-467 } \\ & \text { ISSN 2549-1164 (online) } \\ & \text { Available online at https:/ / ejournal.unibabwi.ac.id/ index.php/ transformasi }\end{aligned}$

\title{
PENGARUH MODEL PEMBELAJARAN ASSURE TERHADAP KREATIVITAS DAN HASIL BELAJAR MATEMATIKA PESERTA DIDIK
}

\author{
Andi Asma \\ Fakultas Tarbiyah dan Ilmu Keguruan IAIN Manado \\ Email korespondensi: andi.asma@iain-manado.ac.id
}

Diterima : (22-02-2021), Revisi: (23-04-2021), Diterbitkan : (20-05-2021)

\begin{abstract}
ABSTRAK
Penelitian ini bertujuan untuk mengetahui perbedaan kreativitas dan hasil belajar dengan menggunakan model assure dan model ekspositori dalam pembelajaran matematika. Model assure dipilih karena memiliki kelebihan adanya keterlibatan siswa. Jenis penelitian ini adalah penelitian eksperimental dengan model rancangan factorial design. Populasi penelitian ini adalah seluruh peserta didik MA terakreditasi B di Samarinda. Teknik pengambilan sampel dilakukan secara acak bertahap (multistage random sampling), yaitu peserta didik Kelas X MA Al Uswah dan Kelas X MA Muslimin Indonesia Center. Teknik pengumpulan data dilakukan dengan tes berbentuk essay untuk mengetahui kreativitas dan hasil belajar. Teknik analisis data dilakukan dengan analisis deskriptif dan analisis inferensial. Hasil penelitian menunjukkan bahwa kreativitas peserta didik dengan model pembelajaran assure memiliki aspek kelancaran 59,11\%, keluwesan 47,14\%, dan keaslian 49,09\% dengan rerata skor 74,56 dan standar deviasi 2,71 sedangkan kreativitas yang dengan pembelajaran ekspositori memiliki tingkat kreativitas dari aspek kelancaran $47,7 \%$, keluwesan 43,49\%, dan keaslian 43,62\% dengan skor rata-rata 64,68 dan standar deviasi 2,12. Hasil belajar dengan model assure termasuk dalam kategori tinggi. Sedangkan hasil belajar dengan model ekspositori berada pada kategori sedang. Hal ini menunjukkan bahwa terdapat perbedaan kreativitas dan hasil belajar antara pembelajaran dengan model assure dan ekspositori.

Kata kunci: Assure, Ekspositori, Kreativitas, Hasil Belajar Matematika
\end{abstract}




\begin{abstract}
This study aims to determine differences in creativity and learning outcomes using the assure model and expository models in mathematics learning. The assure model was chosen because it has the advantage of student involvement. This research is experimental with a factorial design model. The population of this study were all students in MA accredited B in Samarinda. The sampling techniques was carried out in multistage random sampling technique, namely students of Class X MA Al Uswah and Class X MA Muslimin Indonesia Center. The data collection technique was done by using an-essay-shaped test to determine creativity and learning outcomes. The data analysis technique used descriptive analysis and inferential analysis. The results showed that the creativity of students with the assure learning model had aspects of fluency $59.11 \%$, flexibility of $47.14 \%$, and authenticity of $49.09 \%$ with a mean score of 74.56 and a standard deviation of 2.71 while the creativity with expository learning has a level of creativity from the aspect of fluency of $47.7 \%$, flexibility of $43.49 \%$, and authenticity of $43.62 \%$ with an average score of 64.68 and a standard deviation of 2.12. Learning outcomes with the assure model are in the high category. While the learning outcomes with the expository model are in the medium category. This shows that there are differences in creativity and learning outcomes between learning with the assure model and expository models.
\end{abstract}

Key words: Assure, Expository, Creativity, Mathematics Learning Outcomes

\title{
Pendahuluan
}

Penggunaan model dan metode pengajaran yang tepat sangat mempengaruhi daya ingat peserta didik dan keberhasilan proses belajar mengajar. Keberhasilan proses belajar mengajar akan tercapai jika komponen utama dalam proses pembelajaran saling mendukung. Komponen ini terdiri dari bahan belajar, peserta didik, guru, metode pengajaran dan lingkungan belajar. Peserta didik dan aktivitasnya baik sebagai subjek maupun objek dalam proses belajar mengajar, sedangkan guru dapat menjadi subjek sekaligus objek dalam proses belajar mengajar. Selain itu, guru bisa dikatakan sebagai sutradara sekaligus aktor. Dengan demikian peran seorang guru sangat penting dalam keberhasilan belajar peserta didik. Metode yang digunakan guru dalam menyampaikan pelajaran akan sedikit berpengaruh terhadap hasil belajar peserta didik (Sudjana, 2017).

Kreativitas dapat dipandang sebagai bentuk intelegensi. Kreativitas merupakan komponen penting dalam proses belajar. Tanpa kreativitas peserta didik hanya akan bekerja pada sebuah tingkat kognitif yang sempit. Kreativitas adalah kemampuan membuat kombinasi baru, berdasarkan data, informasi, atau elemen 
yang ada. Dalam hal ini kreativitas ditekankan pada produk kreatif, yaitu hasil kreativitas yang merupakan gabungan dari hal-hal yang telah ada sebelumnya yang diperoleh dari pengalaman di sekolah dan dipelajari dalam keluarga dan masyarakat (Sukmadina, 2011). Kreativitas (creative thingking) adalah kemampuan berdasarkan data atau informasi yang tersedia untuk menemukan banyak kemungkinan jawaban atas suatu soal yang menitikberatkan pada kuantitas, kegunaan dan keragaman jawaban. Secara operasional kreativitas dapat dirumuskan sebagai kemampuan yang mencerminkan kelancaran, keluwesan dan keaslian dalam berfikir serta kemampuan untuk mengelaborasi (Siswono, 2014). Kreativitas merupakan aspek yang sangat penting yang harus dimiliki oleh peserta didik.

Aspek kreatifitas peserta didik akan membantu menjelaskan dan mengiterpretasikan konsep-konsep yang abstrak, sehingga memungkinkan peserta didik untuk mencapai penguasaan yang lebih besar, khususnya dalam mata pelajaran matematika dan sains seringkali sulit dipahami. Mata pelajaran matematika adalah suatu pelajaran dasar yang diberikan disetiap tingkat pendidikan dari tingkat sekolah dasar sampai perguruan tinggi. Dalam matematika terdapat banyak rumus-rumus, angka-angka maupun perhitungan-perhitungan (Novitasari, 2016).

Berdasarkan tinjauan beberapa literatur penelitian yang relevan yang dilakukan di SMAN 1 Cikalong wetan, SMK Negeri 1 Bogor, dan SDN 2 Limbo Makmur Kecamatan Bumi Raya bahwa dalam pembelajaran model assure dapat meningkatkan hasil belajar, motivasi belajar dan prestasi belajar. Hasil belajar merupakan sesuatu yang telah dicapai peserta didik setelah melaksanakan kegiatan pembelajaran. Proses pembelajaran yang dialami peserta didik menghasilkan perubahan dalam bidang pengetahuan, pemahaman, keterampilan, nilai dan sikap. Hasil belajar merupakan tolak ukur berhasil tidaknya seorang peserta didik dalam proses pembelajaran. Oleh karena itu tanggung jawab seorang guru adalah guru harus mampu menciptakan proses belajar mengajar dengan suasana kelas yang aktif agar peserta didik merespon pembelajaran dengan baik dan peserta didik tidak merasa bosan. Untuk menciptakan suasana kelas yang aktif sedemikian rupa seorang guru harus mampu menggunakan model pembelajaran yang menarik dan sesuai dengan materi yang akan dijelaskan. Pemilihan model yang tepat menjadikannya salah satu faktor pendukung dalam proses pembelajaran yang dapat membentuk pengetahuan dan pemahaman konsep peserta didik. Salah satu model pembelajaran yang tepat untuk meningkatkan kreativitas dan hasil belajar peserta 
didik adalah dengan menggunakan model assure (Eva, 2016; Kimia, 2016; Maisaroh, 2012; Sulastri, 2014).

Model assure yang merupakan model desain pembelajaran yang dikembangkan untuk menciptakan kegiatan pembelajaran yang efektif dan efisien. Model desain pembelajaran assure menggambarkan langkah-langkah yang sistematik dan menyeluruh tentang aktivitas yang dilakukan untuk medesain program pembelajaran yang sukses (Pribadi, 2011). Salah satu karakteristik yang dianalisis pada model assure adalah pengetahuan awal (Gunawan, 2017). Model assure merupakan model desain pembelajaran yang dikembangkan untuk menciptakan kegiatan pembelajaran yang efektif dan efisien. Model desain pembelajaran assure menggambarkan langkah-langkah yang sistematik dan menyeluruh tentang aktivitas yang dilakukan untuk medesain program pembelajaran yang sukses (Pribadi, 2011).

Model pembelajaran assure adalah model yang paling sederhana untuk pembelajaran. Model ini didasarkan pada pemanfaatan teknologi dan media, serta dikembangkan melalui pemilihan dan pemanfaatan metode, bahan ajar dan peran peserta didik dalam proses pembelajaran. Model pembelajaran assure memiliki beberapa metode yang dapat kita gunakan, yaitu belajar kooperatif, penemuan, pemecahan masalah, diskusi, latihan berulang, tutorial, demonstrasi, presentasi, permainan dan simulasi (Pribadi, 2011). Dalam desain model pembelajaran assure terdapat beberapa hal penting yang harus dilakukan dalam kegiatan pembelajaran sehingga mampu meningkatkan kreativitas dan hasil belajar yaitu analisis karakter siswa, menetapkan kompetensi, memilih metode, media dan bahan ajar, pemanfaatan bahan ajar, melibatkan siswa dan evaluasi dan revisi.

Realitas di lapangan menunjukkan bahwa dalam pembelajaran matematika model pembelajaran masih didominasi oleh pembelajaran ekspositori. Hal tersebut diperkuat berdasarkan hasil observasi dan wawancara terbatas yang penulis lakukan dengan guru matematika di beberapa SMA / MA di Kota Samarinda yang terakreditasi B antara lain MA Muslimin Center Indonesia dan MA Al-Uswah belum memenuhi harapan karena perencanaan dan pelaksanaan pembelajaran guru masih dominan dengan metode transfer materi dan masih menggunakan pembelajaran ekspositori inilah diduga salah satu faktor penyebab rendahnya kreativitas dan hasil belajar peserta didik. Dengan model pembelajaran tersebut diduga terdapat pengaruh model pembelajaran assure terhadap kreativitas dan 
hasil belajar matematika.

\section{Metode Penelitian}

Penelitian ini berjenis penelitian eksperimental dengan menerapkan model pembelajaran assure dan ekspositori untuk melihat pengaruhnya terhadap kreativitas dan hasil belajar peserta didik. Variabel moderator adalah variabel yang mempengaruhi hubungan antara independen dengan dependen, serta bertindak sebagai variabel independen kedua (Sudaryono, 2013). Jadi dalam penelitian ini Model assure sebagai independen pertama dan model ekspositori sebagai independen kedua. Penelitian eksperimental ini menggunakan model rancangan factorial design (Ananda, 2018; Widarjono, 2015). Adapun tabel rancangan penelitian sebagai berikut.

Tabel 1. Rancangan Penelitian

\begin{tabular}{c|c|c|c}
\hline \multicolumn{3}{c}{ Model } \\
\hline \multicolumn{2}{c|}{ Assure ( A1) } & \multicolumn{2}{c}{ Ekspositori (A2) } \\
\hline \multicolumn{2}{c|}{$\mathrm{Y}=(\mathrm{Y} 1, \mathrm{Y} 2)$} & \multicolumn{2}{c}{$\mathrm{Y}=(\mathrm{Y} 1, \mathrm{Y} 2)$} \\
\hline $\mathrm{Y} 1.1$ & $\mathrm{Y} 1.2$ & $\mathrm{Y} 2.1$ & $\mathrm{Y} 2.2$ \\
\hline
\end{tabular}

Keterangan :

$\mathrm{Y}=(\mathrm{Y} 1, \mathrm{Y} 2) \quad$ : Vektor nilai rata-rata

Y1 : Kreativitas

Y2 : Hasil Belajar

A1 : Assure

A2 : Ekspositori

Populasi penelitian ini adalah peserta didik MA dengan Akreditasi B di Kota Samarinda yaitu MA Al-Uswah Samarinda sebanyak 16 peserta didik dan MA Muslimin Center Indonesia Samarinda sebanyak 16 peserta didik. Teknik pengambilan sampel dilakukan dengan menggunakan multistage random sampling. Sampel penelitian adalah peserta didik kelas X MA Muslimin Center Indonesia Samarinda sebagai kelas eksperimen 1 dan peserta didik kelas X MA Al-Uswah Samarinda sebagai kelas eksperimen 2.

Untuk mengumpulkan data digunakan instrumen dalam penelitian ini berupa tes hasil belajar dalam bentuk essay. Tes inilah yang digunakan untuk mengukur hasil belajar sekaligus kreativitas dalam menyelesaikan soal matematika. Contoh kisi-kisi tes hasil belajar dan kreativitas dapat dilihat dalam tabel 2, rubrik 
penilaian hasil belajar dapat dilihat pada tabel 3, dan rubrik penilaian kreativitas dapat dilihat pada tabel 4 .

Tabel 2. Kisi-kisi Tes Hasil Belajar dan Kreativitas

\begin{tabular}{|c|c|c|}
\hline Kompetesi Dasar & Aspek yang dinilai (Kreativitas) & $\begin{array}{c}\text { Aspek yang dinilai } \\
\text { Tes Hasil Belajar }\end{array}$ \\
\hline \multirow{3}{*}{$\begin{array}{l}\text { Menghitung ukuran } \\
\text { pemusatan, ukuran } \\
\text { letak, dan ukuran } \\
\text { penyebaran data, } \\
\text { serta penafsirannya }\end{array}$} & $\begin{array}{l}\text { Menghasilkan banyak ide atau banyak } \\
\text { gagasan (pertanyaan atau pernyataan) } \\
\text { dari informasi yang diberikan dengan } \\
\text { tepat (Fluency) }\end{array}$ & $\begin{array}{lr}\text { Semua } & \text { jawaban } \\
\text { benar ditunjukkan } \\
\text { dengan alasan dan } \\
\text { pola yang sesuai }\end{array}$ \\
\hline & $\begin{array}{ll}\text { Mengemukakan strategi-strategi } & \text { yang } \\
\text { beragam (beragam ide) } & \text { pada } \\
\text { pernyataan atau pertanyaan } & \text { yang } \\
\text { dibuatnya (flexibility) } & \\
\end{array}$ & $\begin{array}{l}\text { Ada jawaban tetapi } \\
\text { tidak sesuai }\end{array}$ \\
\hline & $\begin{array}{l}\text { Memunculkan ide-ide yang unik dalam } \\
\text { menyusun pertanyaan atau pernyataan } \\
\text { dengan tepat (originality) }\end{array}$ & Tidak ada jawaban \\
\hline
\end{tabular}

Tabel 3. Rubrik Penilaian Hasil Belajar

\begin{tabular}{lc}
\hline \multicolumn{1}{c}{ Langkah-Langkah Aspek yang diamati } & Skala Penilaian \\
\hline $\begin{array}{l}\text { Semua jawaban benar ditunjukkan dengan } \\
\text { alasan dan pola yang sesuai }\end{array}$ & 2 \\
\hline Ada jawaban tetapi tidak sesuai & 1 \\
\hline Tidak ada jawaban & 0 \\
\hline
\end{tabular}

Tabel 4. Rubrik Penilaian Kreativitas

\begin{tabular}{lllc}
\hline \multicolumn{1}{c}{ Kelancaran } & \multicolumn{1}{c}{ Keluwesan } & \multicolumn{1}{c}{ Keaslian } & Skor \\
\hline Semua soal diselesaikan & Semua jawaban memi- & Semua ide sesuai & 4 \\
dengan cepat dan benar & liki keragaman sesuai & dengan langkah & \\
serta jawaban sesuai den- & dengan lang- & -langkah penyelesaian & \\
gan langkah-langkah pe- & kah-langkah penyele- & soal \\
nyelesaian soal & saian soal & - Menuliskan apa & \\
- Menuliskan apa yang & - Menuliskan apa yang & \multicolumn{2}{l}{ yang diketahui dan } \\
diketahui dan ditanya- & diketahui dan dita- & ditanyakan \\
kan & nyakan & - Menuliskan rumus \\
- Menuliskan rumus & - Menuliskan rumus & - Memecahkan masa- \\
- Memecahkan masalah & - Memecahkan masa- & \multicolumn{2}{l}{ lah } \\
- Menulis himpunan pe- & lah & - Menulis himpunan & \\
\hline
\end{tabular}




\begin{tabular}{|c|c|c|c|}
\hline nyelesaian & $\begin{array}{l}\text { - Menulis himpunan } \\
\text { penyelesaian }\end{array}$ & penyelesaian & \\
\hline $\begin{array}{l}\text { Sebagian besar soal dis- } \\
\text { elesaikan dengan cepat } \\
\text { dan tepat menggunakan } \\
\text { langkah-langkah penyele- } \\
\text { saian soal } \\
\text { - Menuliskan apa yang } \\
\text { diketahui dan ditanya- } \\
\text { kan } \\
\text { - Menuliskan rumus } \\
\text { - Memecahkan masalah }\end{array}$ & $\begin{array}{l}\text { Sebagian besar jawa- } \\
\text { ban beragam dan dis- } \\
\text { elesaikan dengan lang- } \\
\text { kah-langkah penyele- } \\
\text { saian soal } \\
\text { - Menuliskan apa yang } \\
\text { diketahui dan dita- } \\
\text { nyakan } \\
\text { - Menuliskan rumus } \\
\text { - Memecahkan masa- } \\
\text { lah }\end{array}$ & $\begin{array}{l}\text { Sebagian besar ide } \\
\text { sesuai dengan lang- } \\
\text { kah-langkah penyele- } \\
\text { saian soal. } \\
\text { - Menuliskan apa } \\
\text { yang diketahui dan } \\
\text { ditanyakan } \\
\text { - Menuliskan rumus } \\
\text { - Memecahkan masa- } \\
\text { lah }\end{array}$ & 3 \\
\hline $\begin{array}{l}\text { Sebagian kecil soal disele- } \\
\text { saikan dengan cepat dan } \\
\text { tepat dengan lang- } \\
\text { kah-langkah penyelesaian } \\
\text { soal } \\
\text { - } \quad \text { Menuliskan apa yang } \\
\quad \text { diketahui dan dita- } \\
\quad \text { nyakan } \\
\text { - Menuliskan rumus } \\
\end{array}$ & $\begin{array}{l}\text { Tidak ada keragaman } \\
\text { tetapi sebagian kecil } \\
\text { sesuai dengan lang- } \\
\text { kah-langkah penyele- } \\
\text { saian soal } \\
\text { - } \quad \text { Menuliskan apa } \\
\quad \text { yang diketahui dan } \\
\text { ditanyakan } \\
\text { - } \quad \text { Menuliskan rumus } \\
\end{array}$ & $\begin{array}{l}\text { Sebagian ide sesuai } \\
\text { dengan lang- } \\
\text { kah-langkah penyele- } \\
\text { saian soal } \\
\text { - } \quad \text { Menuliskan apa } \\
\quad \text { yang diketahui } \\
\text { dan ditanyakan } \\
\text { - } \quad \text { Menuliskan rumus }\end{array}$ & 2 \\
\hline $\begin{array}{l}\text { Semua soal diselesaikan } \\
\text { dengan waktu yang lama } \\
\text { dan tidak benar, serta tidak } \\
\text { sesuai dengan lang- } \\
\text { kah-langkah penyelesaian } \\
\text { soal } \\
\text { - Menuliskan apa yang } \\
\text { diketahui dan ditanya- } \\
\text { kan }\end{array}$ & $\begin{array}{l}\text { Semua jawaban tidak } \\
\text { beragam dengan lang- } \\
\text { kah-langkah penyele- } \\
\text { saian soal } \\
\text { - Menuliskan apa yang } \\
\text { diketahui dan dita- } \\
\text { nyakan }\end{array}$ & $\begin{array}{l}\text { Ide- ide tidak sesuai } \\
\text { dengan lang- } \\
\text { kah-langkah penyele- } \\
\text { saian soal } \\
\text { - Menuliskan apa } \\
\text { yang diketahui dan } \\
\text { ditanyakan }\end{array}$ & 1 \\
\hline Tidak ada jawaban & Tidak ada jawaban & Tidak ada jawaban & 0 \\
\hline
\end{tabular}

Teknik analisis data dalam penelitian ini adalah analisis deskriptif dan analisis inferensial one-way multivariate analysis of variance (Abdul, 2019). Variabel dalam penelitian ini adalah variabel bebas berupa model pembelajaran assure dan ekspositori sedangkan variabel terikatnya adalah kreativitas dan hasil belajar peserta didik dalam pembelajaran matematika. Adapun defenisi operasional hasil belajar peserta didik yang dimaksud dalam penelitian ini adalah skor tes hasil 
belajar yang diperoleh peserta didik yang diberi perlakuan dengan model pembelajaran assure dan ekspositori. Kreativitas yang dimaksud dalam penelitian ini adalah skor tes kreativitas dalam menyelesaikan soal matematika yang meliputi aspek kelancaran, keluwesan dan keaslian dengan model pembelajaran assure dan ekspositori.

Pengumpulan data dalam penelitian ini dilakukan dengan dua tahap. Tahap pertama setelah kegiatan pembelajaran (pemberian perlakuan) pada kelas eksperimen 1 dan kelas eksperimen 2, peserta didik diberikan tes untuk mengetahui hasil belajar dan kreativitas peserta didik dalam menyelesaikan soal matematika dengan bentuk soal yang sama untuk kedua kelompok tersebut. Tahap kedua setelah pemberian tes hasil belajar dalam bentuk essay untuk mengukur hasil belajar dan kreativitas, dilakukan pemeriksaan hasil tes berdasar pada rubrik penilaian hasil belajar dan kreativitas dan selanjutnya dilakukan pengolahan data secara statistik baik deskriptif maupun inferensial.

\section{Hasil dan Pembahasan}

Terdapat perbedaan kreativitas dan hasil belajar dengan pembelajaran assure dan pembelajaran ekspositori. Nilai rata-rata kreativitas dalam menyelesaikan soal pada model assure adalah 74,56 dan hasil belajar peserta didik adalah 80,00. Pada kelas eksperimen 2, nilai rata-rata kreativitas peserta didik dalam menyelesaikan soal matematika yang diberi perlakuan dengan ekspositori adalah 64,68 dan nilai rata-rata hasil belajar peserta didik adalah 74,00. Gambar 1 menunjukkan persentase hasil belajar pada kelas eksperimen 1 dan kelas eksperimen 2 .

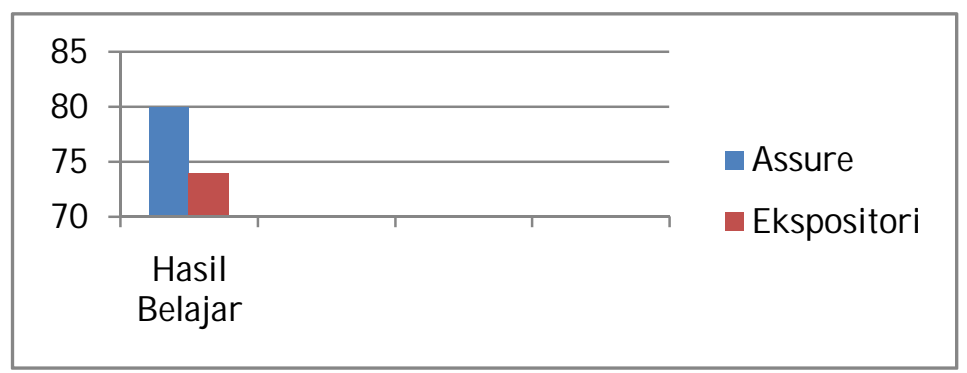

Gambar 1. Persentase Hasil Belajar Kelas Eksperimen 1 dan 2

Dari uraian di atas, dapat disimpulkan bahwa terdapat perbedaan rata-rata kreativitas dan hasil belajar dengan model assure (kelas eksperimen 1) dan ekspositori (kelas eksperimen 2). Rata-rata kreativitas dan hasil belajar peserta didik 
dengan model assure lebih besar dibandingkan dengan kelas yang diberi perlakuan dengan ekspositori. Hal ini terlihat dari pengamatan peneliti pada saat penelitian, peserta didik yang diajar dengan model assure menjadi lebih tertarik untuk mengikuti proses belajar mengajar, peserta didik lebih aktif, bebas bertanya atau bertanya terkait dengan pembelajaran. materi yang sedang dipelajari serta menyiapkan jawaban. Dari pertanyaan-pertanyaan yang disusun dalam kelompok. Mereka berusaha mencari solusi untuk setiap soal, peran guru tidak terlalu dominan. Guru berperan sebagai fasilitator dalam proses belajar mengajar. Dengan demikian pengetahuan yang ditemukan jauh lebih bermakna jika dibandingkan dengan ekspositori.

Hasil analisis statistik inferensial, sebelum melakukan analisis inferensial terlebih dahulu dilakukan uji asumsi yaitu uji normalitas dan uji homogenitas (Sugiyono, 2017).

\section{Uji Normalitas}

Pengujian normalitas bertujuan untuk mengetahui apakah data kreativitas dan hasil belajar berasal dari populasi berdistribusi normal. Berdasarkan uji normalitas, untuk kreativitas peserta didik dalam menyelesaikan soal matematika pada pembelajaran assure diperoleh nilai probabilitas $=0,187>\alpha=0,05$ dan berdasarkan data kurva normal nilai kreativitas peserta didik dalam menyelesaikan soal matematika mengikuti nilai garis normal, dalam pembelajaran ekspositori nilainya $0,610>\alpha=0,05$ dan mengikuti garis normal. Sedangkan hasil belajar peserta didik pada pembelajaran assure diperoleh nilai probabilitas $=0,168>\alpha=$ 0,05 dan berdasarkan kurva normal data hasil belajar mengikuti garis normal dan pada pembelajaran ekspositori nilai probabilitas sebesar 0,326 $>\alpha=0,05$ mengikuti garis normal. Dengan demikian dapat disimpulkan bahwa data nilai kreativitas siswa dalam menyelesaikan soal matematika dan hasil belajar berasal dari populasi yang berdistribusi normal.

\section{Uji Homogenitas}

Pengujian homogenitas bertujuan untuk mengetahui apakah skor kreativitas dan hasil belajar berasal dari populasi yang homogen. Berdasarkan uji homogenitas, pada kolom Box's Test of Equality of Covariance Matricesa nilai $F=0,582$ dan p-value $=0,627$ dengan mengambil nilai $\alpha=0,05$, maka p-value $>0,05$ sehingga $H_{0}$ diterima dan $H_{1}$ ditolak yang menyatakan bahwa kedua variabel atau data skor kreativitas peserta didik dalam menyelesaikan soal matematika dan hasil belajar 
homogen. Untuk menjawab hipotesis penelitian dengan menggunakan uji T dan analisis ragam multivariate satu arah One-Way Multivariate Analysis Of Variance (Abdul, 2019).

Hasil analisis juga menunjukkan bahwa rata-rata kreativitas peserta didik yang diberi perlakuan dengan model assure berbeda nyata dengan model ekspositori dengan nilai statistik $\mathrm{t}=11,847$ dengan $\mathrm{dk}=30$ dan nilai $\mathrm{p}$-sign $=0,000$. Karena nilai $\mathrm{p}$-sign $=0,000<\alpha=0,05$ maka diputuskan untuk menolak 0 (nol). Dengan demikian dapat disimpulkan bahwa terdapat perbedaan kreativitas yang diberi perlakuan dengan model pembelajaran assure dengan pembelajaran ekspositori. Artinya model assure memberikan hasil yang signifikan terhadap kreativitas peserta didik dalam menyelesaikan soal matematika.

Indikator kelancaran adalah peserta didik banyak menghasilkan ide atau gagasan dari informasi yang diberikan. Pada kelas eksperimen 1, soal diselesaikan dengan kecepatan jawaban cepat dan benar serta jawaban sesuai dengan langkah-langkah pemecahan soal yang sebenarnya dimana aspek kelancaran adalah 59,11\%. Pada kelas eksperimen 2 aspek kelancaran 47,70\%. Indikator keluwesan adalah menggunakan berbagai strategi (keragaman ide) dalam jawaban yang dibuatnya. Pada kelas eksperimen 1 memberikan variasi jawaban pada aspek keluwesan sebesar 47,14\% sedangkan pada kelas eksperimen 2 aspek keluwesan $43,49 \%$. Indikator keaslian adalah peserta didik dapat memunculkan ide-ide unik dalam menyusun jawaban dengan tepat. Pada kelas eksperimen 1 aspek keaslian 49,09\% sedangkan pada kelas eksperimen 2 dengan pembelajaran ekspositori $43,62 \%$.

Pada penelitian ini menunjukkan kreativitas siswa yang merupakan karakter positif yang harus ada dalam pendidikan matematika perlu dikembangkan dengan kebutuhan berkembangnya sikap kreatif ilmiah siswa dalam menghadapi arus global yang sudah maju. Hal ini sesuai dengan penelitian sebelumnya yang menunjukkan bahwa secara keseluruhan besar peningkatan kreativitas siswa terdiri atas aspek kelancaran (fluency), keluwesan (flexibility), keaslian (originality), ingatan (memory), dan kesadaran (awareness) (Pamungkas, 2017). Adapun persentase skor kreativitas kelas eksperimen 1 dan 2 dapat dilihat pada gambar 2 . 


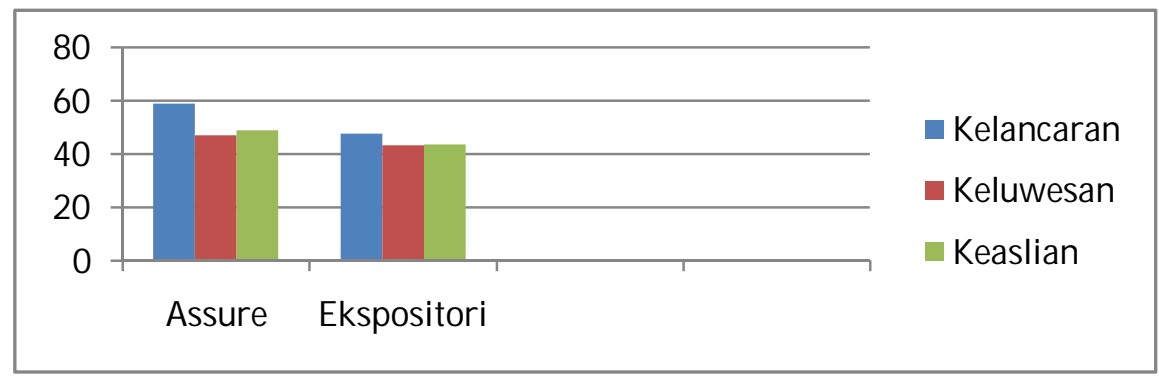

Gambar 2. Persentase Skor Kreativitas Kelas Eksperimen 1 dan 2

Hasil analisis juga menunjukkan bahwa rata-rata hasil belajar peserta didik yang diberi perlakuan dengan model pembelajaran assure dan pembelajaran ekspositori berbeda secara signifikan dengan nilai statistika $t=5.132$ dengan $\mathrm{dk}=30$ dan tanda p-nilai $=0,000$. Karena nilai p-sign $=0,000<\alpha=0,05$ maka diputuskan menolak 0 (nol). Dengan demikian dapat disimpulkan bahwa terdapat perbedaan hasil belajar dan kreativitas dengan pembelajaran model assure dan ekspositori pada kelas eksperimen 1 dan kelas eksperimen 2.

\section{Kesimpulan}

Terdapat perbedaan kreativitas siswa yang diberi perlakuan dengan model pembelajaran assure dan ekspositori. Pada kelas eksperimen 1 memiliki tingkat kreativitas dalam menyelesaikan soal matematika pada aspek kelancaran 59,11\%, keluwesan 47,14\%, dan keaslian 49,09\% dengan skor rata-rata 74.56 dan standar deviasi 2.71. Pada kelas eksperimen 2 memiliki aspek kelancaran 47,7\%, keluwesan $43,49 \%$ dan keaslian 43,62\% dengan skor rata-rata 64,68. dan standar deviasi 2.12 .

Terdapat perbedaan hasil belajar siswa yang diberi perlakuan dengan model pembelajaran assure dan pembelajaran ekspositori. Pada kelas eksperimen 1 terdapat $87,5 \%$ pada kategori tinggi dengan nilai rata-rata 80,00 dan standar deviasi 3.65. Pada eksperimen 2 adalah $62,4 \%$ pada kategori sedang dan skor rata-rata 64,68 dan standar deviasi 2,12.

\section{Daftar Pustaka}

Abdul, F. dkk. (2019). Statistik Multivariate. Rajawali Pers.

Amrullah. (2018). Studi Sistematik Aspek Kreativitas dalam Konteks Pendidikan.

Psympathic: Jurnal Ilmiah Psikologi, 5(2), 187-200. 
https:/ / doi.org/ 10.15575/ psy.v5i2.3533

Ananda, R. dkk. (2018). Statistik Pendidikan. CV. Widia Puspita.

Eva, R. (2016). Pengaruh Aplikasi Model Assure Terhadap Motivasi Dan Hasil Belajar Peserta Didik Dalam Pembelajaran Geografi. Jurnal Geografi Gea, 15(2), 8-14. https:// doi.org/ 10.17509/ gea.v15i2.3543

Gunawan. (2017). Pengaruh Model Pembelajaran Assure dan Pengetahuan Awal Terhadap Hasil Belajar IPA-Fisika Siswa Kelas VIII SMPN 22 Mataram. Jurnal Pendidikan Fisika Dan Teknologi 1(3):166 DOI: 10.29303/Jpft.V1i3.254.

Mahmudi, A. (2008). Tinjauan Kreativitas dalam Pembelajaran Matematika. Pythagoras: Jurnal Pendidikan Matematika, 4(2), 37-49. https:/ / doi.org/ 10.21831/ pg.v4i2.559

Maisaroh, R. (2012). Peningkatan Hasil Belajar Siswa Dengan Menggunakan Metode Pembelajaran Active Learning Tipe Quiz Team Pada Mata Pelajaran Keterampilan Dasar Komunikasi Di SMK Negeri 1 Bogor. Jurnal Ekonomi Dan Pendidikan, 7(2), 157-172. https:/ / doi.org/ 10.21831/ jep.v7i2.571

Maya Sari, W. (2016). Penerapan Model Assure Dengan Metode Problem Solving Untuk Meningkatkan Keterampilan Berpikir Kritis. Jurnal Inovasi Pendidikan Kimia, 9(1), 1468-1477.

Nawawi. (2018). Mendesain Pembelajaran Efektif Berdasarkan Model ASSURE. Prosiding PKM-CSR, VOL. 1 (2018), 1, 1302-1307.

Pamungkas. (2017). Implementasi model pembelajaran IPA berbasis kearifan lokal untuk meningkatkan kreativitas dan hasil belajar siswa. Jurnal Inovasi Pendidikan IPA, 3(2), 118. https:/ / doi.org/10.21831/jipi.v3i2.14562

Pradnya, N. W. (2014). Model Pembelajaran Assure Bernuansa Lingkungan Berbantuan Media Audiovisual Berpengaruh Terhadap Hasil Belajar IPS Siswa Kelas V SD Gugus Letkol Wisnu Jurusan Pendidikan Guru Sekolah Dasar, FIP Universitas Pendidikan Ganesha. Jurnal Mimbar PGSD Universitas Pendidikan Ganesha Jurusan PGSD, 2.

Pribadi, B. A. (2011). Model Assure untuk Mendesain Pembelajaran Sukses. Dian Rakyat.

Sasmita. (2015). Kemampuan Berpikir Kreatif Siswa dalam Pembelajaran Problem Posing pada Materi Bangun Datar. Pendidikan Dan Pembelajaran, 4(1), 1-16.

Siswono, T. Y. E. (2014). Desain Tugas untuk Mengidentifikasi Kemampuan Berpikir Kreatif Siswa dalam Matematika. 2014. 
Sudaryono. (2013). Pengembangan Instrumen Penelitian Pendidikan. Graha Ilmu.

Sudjana, N. (2017). Penilaian Hasil Proses Belajar Mengajar. Remaja Rosdakarya.

Sugiyono. (2017). Metode Penelitian Kombinasi (Mixed Methods). Alfabeta.

Sukmadina. (2011). Landasan Psikologis Proses Pendidikan. Remaja Rosdakarya.

Suryana, A. (2013). Pengaruh Penggunaan Model Pembelajaran. 1(November 2012),

58-69. https:/ / doi.org/ 10.1021/ ie50479a043

Widarjono, A. (2015). Statistika Terapan. UPP STIM YKPN. 